Bull. Environm. Contam. Toxicol. 29, 58-63 (1982)

\title{
Association Studies of Polybrominated Biphenyls in Aquatic Systems
}

\author{
Milagros S. Simmons and Karen T. Kotz \\ Department of Environmental and Industrial Health, The University of \\ Michigan, Ann Arbor, MI 48109
}

Most of the studies on polybrominated biphenyls (PBB) have been on toxicological evaluations. Very few studies have dealt with their persistence and concentration potential in several environmental matrices such as soil, sediments, and biota as a function of matrix properties. The understanding of these relationships will form some basis for assessing the characteristics of the contaminant's behavior in the environment.

Our study deals with the factors that determine the mode of action $\mathrm{PBB}$ may take in its movement through the water column to its deposition and adsorption onto the sediments, which are potential sources as well as sinks for most chemicals. Several factors influence the adsorption process. A controversy continues to exist over the influence of particle size and type of sediment versus the organic content of the sediment on adsorption. LELAND et al. (1973), CHOI \& CHEN (1976) and SIMMONS et a1. (1980) have shown that organic content of the sediment is directly related to the adsorptive capacity of the sediment for a specific contaminant. KARICHOFF et al. (1979) believe that organic content of the sediment is the most significant factor in the adsorption process. SCHWARZENBACH \& WESTALL (1981) indicate that adsorption of nonpolar compounds was highly correlated to the organic carbon content of sorbents with greater than $0.1 \%$ organic carbon.

Desorption from the sediments of the contaminant however, is favored where high concentration of organic matter in the water column exists (HUANG 1971). The presence of organic matter in the water column may also enhance the partitioning of the contaminant in the water column and thus facilitate further movement with the water mass (HASSETT \& ANDERSON 1979).

Our study, therefore, examined not only the influence of the organic content of the sediment but also that of the overlying water on the adsorption process. Our results indicate that the total organic content (TOC) of the natural water will decrease the adsorption of $\mathrm{PBB}$ onto the sediment and therefore keep the $\mathrm{PBB}$ in the water phase.

\section{MATERIALS AND METHODS}

Materials and Equipment. The following materials were used: petroleum ether, acetone, hexane (Pesticide Grade, Burdick and Jack- 
son Lab., Inc., Muskegon, MI); liquid scintillation cocktail (ACS type) (Amersham Corp., Arlington Heights, IL); florisi1, (Fisher Scientific Co., Fairlawn, NJ) activated at $60^{\circ} \mathrm{C}$ for $24 \mathrm{~h}$; ${ }^{14} \mathrm{C}-1 \mathrm{a}-$ beled hexabromobiphenyl isomer (specific activity, $10.2 \mathrm{Ci} / \mathrm{mole}$ ) and non-1abelled PBB Firemaster FFL (98\% Firemaster BP-6 plus 2\% anticaking agent (flo-gard, lot 非1312-FT) (National Institute of Environmental Health Sciences, Research Triangle Park, NC); humic acid, (A1drich Chemical Co., Milwaukee, WI), Lot 非 $121137 ; \mathrm{C}=50.5 \%, \mathrm{H}=3.83 \%$ and $\mathrm{N}=0.57 \%$; with very 1 ittle fulvic acid component but a large hymatomelanic acid component and TOC of $173 \mathrm{mg} / \mathrm{L}$; potassium hydrogen phthalate (Fisher Scientific Co., Fairlawn, NJ) for TOC standards.

The equipment used consisted of a Varian Gas Chromatograph, Model 3700 ( $63_{\mathrm{Ni}}$ electron capture detector). Operating parameters: oven temperature $=240^{\circ} \mathrm{C}$; injection port temperature $=260^{\circ} \mathrm{C}$; detector temperature $=300^{\circ} \mathrm{C}$. Carrier gas: nitrogen (flow rate $=50 \mathrm{~mL} / \mathrm{min}$ ), $1.9 \mathrm{~m} \times 2 \mathrm{~mm}$ i.d. coiled glass column with $3 \%$ OV-101 on Gas-Chrom Q, 100/120 mesh, and a Beckman LS 7500 Liquid Scintillation Counting System.

Methods. Sediments and overlying waters were collected from Lake Michigan (Little Traverse Bay) and the Huron River (Hudson Mills and Zeeb Rd.), using ponar grab and Kemmerer samplers. A composite water sample was collected by mixing the water obtained at different depths. Site BR-1 (depth, $73 \mathrm{~m}$ ) and site BR-2 (depth, $80 \mathrm{~m}$ ) were approximately $1.1 \mathrm{mi}$ and $1.5 \mathrm{mi}$, respectively, from Big Rock Point. Sediments and waters were collected from the Huron River at two locations. All sediments and water samples were stored in glass containers at $4^{\circ} \mathrm{C}$ until used. Homogenized sediment samples were wetsieved through a U.S. Standard Sieve $\# 230$ for size fractionation. Analyses were done in duplicates. TOC and $\mathrm{PBB}$ were analyzed in the sediments, natural waters and the distilled water. No PBB was detected in these samples. A statistical computer program package (MIDAS) at the University of Michigan was used for data analysis.

Experiments. 1. Rate Studies. Kinetic studies were performed in a closed reactor system at $20^{\circ} \mathrm{C}$ using a 3-neck, 2-L Pyrex round bottom flask. $50 \mu \mathrm{g} / \mathrm{L}$ non-1abelled $\mathrm{PBB}$ and $25 \mu \mathrm{g} / \mathrm{L}{ }^{14} \mathrm{C}-1 \mathrm{abelled}$ hexabromobiphenyl isomer were added and stirred into $2 \mathrm{~L}$ of water. There was no head space allowed in the flask. The system was then allowed to equilibrate for $1 \mathrm{~h}$, with stirring. This is the time period required to dissolve the $\mathrm{PBB}$ completely and allow the PBB adsorption onto the glass walls of the container to reach equilibrium. An aliquot of the solution was removed at this time $(t=0)$ and then a weighed amount of sediment was added to the system. Subsequent aliquots were taken at 5,10 , and $20 \mathrm{~min}$ and $1,2,4$, and $8 \mathrm{~h}$ from $\mathrm{t}=0$. Each aliquot was extracted with hexane and the hexane extract was counted for radioactivity.

These experiments were conducted for both distilled and natural water/sediment systems. Relationships of the TOC of the water to the adsorptive capacity of the BR-2 sediment was investigated by addition of varying amounts of humic acid in the water. 
Adsorption Isotherms. Adsorption isotherm experiments were performed on different types of sediments using 500-mL ground glassstoppered flasks, containing $400 \mathrm{~mL}$ of water each. Both distilled and natural waters were used as media. Different sediment weights $(0,5,10,15,20,25,35$, and $100 \mathrm{mg})$ and both ${ }^{14} \mathrm{C} \mathrm{PBB}$ and nonlabelled $\mathrm{PBB}$ were added to each flask. The flasks were shaken at $150 \mathrm{rpm}$ on a rotary shaker at $20^{\circ} \mathrm{C}$. After $24 \mathrm{~h}$, a 10-mL aliquot was taken from each flask and extracted with $2 \mathrm{~mL}$ of hexane. The hexane extract was transferred to scintillation vials and counted.

\section{RESULTS AND DISCUSSIONS}

Water and Sediment Characteristics. Table 1 summarizes the sediment, water and humic acid characterization parameters determined. TOC values for sediments ranging from 0.34 to $2.67 \%$ revealed strong positive correlation $(r=0.99)$ with \% silt/clay fraction. This is in accordance with the observations of CHOI \& CHEN (1976), POWERS $\&$ ROBERTSON (1968) and SIMMONS et al. (1980). The positive corre1ation may be explained by greater surface area/volume ratio in silt/ clay particles which give them the ability to accomodate more organic compounds than the course sand particles.

Table 1. Characterization Parameters

\begin{tabular}{|c|c|c|c|c|}
\hline $\begin{array}{l}\text { Sample } \\
\text { Number }\end{array}$ & Site & Matrix & $\mathrm{TOC}^{1}$ & $\begin{array}{l}\text { Percent } \\
\text { Silt/Clay }\end{array}$ \\
\hline $\mathrm{BR}-1$ & Lake Michigan & $\begin{array}{r}\text { Water } \\
\text { Sediment }\end{array}$ & $\begin{array}{l}3.8 \mathrm{mg} / \mathrm{L} \\
0.35 \%\end{array}$ & 14 \\
\hline $\mathrm{BR}-2$ & Lake Michigan & $\begin{array}{r}\text { Water } \\
\text { Sediment }\end{array}$ & $\begin{array}{l}3.8 \mathrm{mg} / \mathrm{L} \\
0.34 \%\end{array}$ & 12 \\
\hline $\mathrm{R}-1$ & $\begin{array}{l}\text { Huron River } \\
\text { Hudson Mills }\end{array}$ & $\begin{array}{r}\text { Water } \\
\text { Sediment }\end{array}$ & $\begin{array}{l}11.7 \mathrm{mg} / \mathrm{L} \\
0.30 \%\end{array}$ & 10 \\
\hline$R-2$ & $\begin{array}{l}\text { Huron River } \\
\text { Zeeb Road }\end{array}$ & $\begin{array}{r}\text { Water } \\
\text { Sediment }\end{array}$ & $\begin{array}{l}12.1 \mathrm{mg} / \mathrm{L} \\
2.67 \%\end{array}$ & 63 \\
\hline $\begin{array}{l}\text { Humic } \\
\text { Acid }\end{array}$ & & Water & $173 \mathrm{mg} / \mathrm{L}$ & \\
\hline
\end{tabular}

${ }^{1}$ A11 values are averages of duplicate analyses. A11 values of TOC are represented as $\mathrm{mg} / \mathrm{L}$ of carbon or percent carbon.

Kinetic Rate Studies in Distilled vs. Natural Waters. Our studies indicate that the amount of PBB adsorbed by the sediments was less in all cases in natural water than in distilled water (Table 2). The percent adsorption that occurred in the 8-h period in distilled water ranged from $9-32 \%$, suggesting smal1 to moderate capacity of the sediments for PBB. No significant difference between 
the correlation of the silt/clay fraction and \% adsorption $(r=0.96)$ vs. the TOC and \% adsorption $(r=0.95)$ was observed. First-order rate constants were obtained by plotting the log concentration of PBB remaining in solution vs. time. No significant correlation between the rate of adsorption and TOC or \% silt/clay of the sediment was found. However, the river sediment with the highest TOC and \% silt/ clay fraction showed highest rate and amount of $\mathrm{PBB}$ adsorption.

Table 2. Comparison of PBB Adsorption in Sediments With Distilled and Natural Waters

\begin{tabular}{llllll}
\hline $\begin{array}{l}\text { Sample } \\
\text { Number }\end{array}$ & Matrix & $\mathrm{r}$ & Significance & $\mathrm{k}$ & $\%$ adsorbed \\
\hline \multirow{2}{*}{ BR-1 } & Distilled & 0.71 & 0.000 & 0.0065 & 16 \\
& Natural & 0.53 & 0.005 & 0.0057 & 14 \\
BR-2 & Distilled & 0.64 & 0.013 & 0.0027 & 9 \\
& Natural & 0.12 & 0.54 & 0.0012 & 8 \\
R-1 & Distilled & 0.81 & 0.001 & 0.0035 & 14 \\
& Natural & 0.83 & 0.014 & 0.0027 & 8 \\
R-2 & Distilled & 0.87 & 0.000 & 0.0108 & 32 \\
& Natural & 0.43 & 0.027 & 0.0059 & 21 \\
\hline
\end{tabular}

Comparing the distilled water vs. natural water systems in river water with organic content of $11-12 \mathrm{mg} / \mathrm{L} \mathrm{C}$, \% adsorption was decreased by $33-43 \%$. For lake water with organic carbon content of $3.8 \mathrm{mg} / \mathrm{L} \mathrm{C}$ adsorption was reduced by about $12 \%$. In the latter case, $k$ values decreased in some cases up to $50 \%$ or more. These observations could be justified by the association of $\mathrm{PBB}$ in the water phase in competition to its adsorption onto the sediments. In the natural environment this association with the water phase may not last, since the contaminant may not be exposed to the dissolved organic matter for great lengths of time due to their deposition with particulate matter to the sediment. Subsequently, upon settling out, the association of the contaminant with the sediment becomes the dominant process in the water/sediment system. We could speculate that a disturbance of the sediments by mixing or bioturbation may cause redistribution of the contaminant in the water column and facilitate further exposure of areas until equilibrium is reestablished. Should the redistribution occur in a riverine system, the association of the contaminant to both dissolved and particulate matter may cause the contaminant to flow downstream to non-contaminated areas.

Adsorption Isotherms. The Freundlich isotherm equation was used to analyze the data obtained to determine the adsorption capacity of the sediments for PBB. The capacity $k$ was determined from the equation: 


$$
\mathrm{Q}_{\mathrm{e}}=\mathrm{kC}^{\mathrm{n}}
$$

where $\mathrm{n}$ is the intensity of the process, and $\mathrm{C}$ is the concentration of $\mathrm{PBB}$ in the remaining solution in $\mathrm{mg} / \mathrm{L}$.

Table 3. Adsorption Isotherms of PBB In Sediment and Distilled Water

\begin{tabular}{lccc}
\hline $\begin{array}{l}\text { Sample } \\
\text { Number }\end{array}$ & $\mathrm{n}$ & $\mathrm{k} \mathrm{\mu g} / \mathrm{L}$ & $\mathrm{r}$ \\
\hline $\mathrm{BR}-1$ & 1.4 & 5.2 & 0.96 \\
$\mathrm{BR}-2$ & 2.1 & 0.63 & 0.89 \\
$\mathrm{R}-1$ & 2.2 & 0.12 & 0.87 \\
$\mathrm{R}-2$ & 0.88 & 123.00 & 0.84 \\
\hline
\end{tabular}

The results in Table 3 show that the sediment with the greatest $\%$ silt/clay and TOC content had the lowest "n" value (0.88). This suggests minimum amount of competition occurring for available sites for this sediment type (KHAN 1974). From the data collected, it is shown that as the \% silt/clay and TOC decrease, the "n" value becomes greater than unity. It becomes evident that the two factors of TOC content and \% silt/clay fraction play an important role in the availability of adsorption sites which in turn affects sediment capacity for adsorption of PBBs. Regression analysis revealed strong correlations ( $r=0.99$ in both cases) between adsorptive capacity of the sediments to TOC content and \% silt/clay fraction.

Effect of TOC in Overlying Water on Adsorption. Further studies elucidating the effect of TOC content of the overlying water on sorption rate of $\mathrm{PBB}$ onto sediments were carried out by adding humic acid to increase the TOC of the water. These studies were performed on sediment $\mathrm{R}-2$. The results shown in Table 4 show that the humic acid did not cause a significant decrease in the amount sorbed from the distilled water but caused a significant decrease in the rate of sorption. Natural water had more of an effect on the \% sorption with TOC $(12.2 \mathrm{mg} / \mathrm{L} \mathrm{C})$ than any of the humic acid additions ranging from 10$52 \mathrm{mg} / \mathrm{L} \mathrm{C}$.

Table 4. Effect of Humic Acid on $k$ and \% Sorption

\begin{tabular}{lccc} 
Matrix & TOC (mg/L) & $k$ & $\%$ sorption \\
\hline & & & \\
Distilled water & 0 & 0.0108 & 32 \\
Natural water & 12 & 0.0059 & 21 \\
Humic Acid & 10 & 0.0004 & 31 \\
Humic Acid & 31 & 0.0004 & 31 \\
Humic Acid & 52 & 0.0003 & 32 \\
\hline
\end{tabular}


Perhaps the nature of the organic carbon in the natural water has a higher portion of soluble organic matter compared to the humic acid we used in this study. The PBB could possibly associate with this soluble portion causing it to increase its "apparent" aqueous solubility or that the nature of the organics in the natural water have binding properties and/or capacities for PBB greater than the humic acid used in this study. In essence, this experiment shows that the TOC content of the overlying water is important in determining adsorptive behavior of sediments, however, it is the nature of the components that make up the TOC fraction that further dictates the sorption process.

Acknowledgement. Research was supported in part by a grant from the State of Michigan Department of Public Health.

\section{REFERENCES}

CHOI, W. and K.Y. CHEN: Environ. Sci. Technol. 10, 782 (1976).

GOERLITZ, D.F. and L.M. LAW: J. Res. US Geological Survey 2, 541 (1974).

HUANG, J.: J. Water Pol1. Contr. Fed. 43, 1739 (1971).

HASSETT, J.P. and M.A. ANDERSON: Environ. Sci. Techno1. 13, 1526 (1979).

KARICHOFF, S.M., D. BROWN, T. SCOTT: Water Res. 13, 241 (1979).

KHAN, S.U.: Environ. Sci. Technol. 8, 236 (1974).

LELAND, H.V., N.W. BRUCE, N.F. SHIMP: Environ. Sci. Technol. 7, 833 (1973).

POWERS, C.F. and A.J. ROBERTSON: Proceedings of the International Great Lakes Conference 3, 305 (1968).

SCHWARZENBACH, R.P. and J. WESTALL: Environ. Sci. Techno1. 15, 1360 (1981).

SIMMONS, M.S., D. BIALSOKY, R. ROSSMAN: J. Great Lakes Res. $\underline{6}, 161$ (1980).

Accepted April 19, 1982 